\title{
Ancient Lake Maxima and Substrate-dependent Riverine Migration Have Defined the Range of the Mudpuppy (Necturus maculosus) in Southern Ontario Following the Wisconsinan Glaciation
}

\author{
Peter B. Mills ${ }^{1,3}$ and DunCAN J. E. Hill ${ }^{2}$ \\ ${ }^{1}$ Algonquin Provincial Park Museum and Visitor Centre, Highway 60, Nipissing District, Whitney, Ontario K0J 2M0 Canada \\ 244 Mullins Lane, Astorville, Ontario P0H 1B0 Canada \\ ${ }^{3}$ Corresponding author: peter.b.mills@hotmail.com
}

\begin{abstract}
Mills, Peter B., and Duncan J. E. Hill. 2016. Ancient lake maxima and substrate-dependent riverine migration have defined the range of the Mudpuppy (Necturus maculosus) in southern Ontario following the Wisconsinan glaciation. Canadian Field-Naturalist 130(2): 158-163.
\end{abstract}

The Mudpuppy (Necturus maculosus) is an entirely aquatic salamander whose geographic range is thus defined by immigration routes in watersheds that permit feasible travel. Significant barriers, such as large waterfalls, effectively bar this species from further colonization upstream. We compared the contemporary distribution of Mudpuppies in southern Ontario with varying post-glacial ancient lake maxima and riverine outlet-flow conditions. Topography does not appear to be a range-limiting factor, but the type of river grade (waterfalls versus riffles) does. The distribution of modern records of this species in Ontario aligns closely with maxima from the Nipissing phase occurring 4000-5000 years ago, leading us to suggest that this is when Mudpuppies invaded and proliferated in the Great Lakes Basin.

Key Words: Mudpuppy; Necturus maculosus; Great Lakes; Wisconsinan glaciation; colonization; distribution

\section{Introduction}

The Mudpuppy (Necturus maculosus [Rafinesque, 1818]) is a large and entirely aquatic salamander. Adults differ from many other salamander species in that they are pedomorphic, retaining their gills into and throughout adulthood. Logically, this limits this species' immigration and range expansion capabilities because they are unable to overcome significant barriers, such as waterfalls, as substantiated by Cochran's (1991) work on the Mississippi River.

During the Wisconsinan glaciation, the Great Lakes region was completely inhospitable to ectotherms, which survived in refugia (Haffer 1969) to the south where more suitable climates prevailed (Mandrak and Crossman 1992a). As the Laurentide Ice Sheet retreated northward and warmer thermal regimes returned to the Great Lakes Basin, these species dispersed northward into suitable environments (Holman 1995). The Mudpuppy would have been one of these species, although unlike other terrestrial herpetofauna, its route of colonization was via waterways only (Hecht and Walters 1955; Mandrak and Crossman 1992a).

We tested whether the Mudpuppy's current distribution in southern Ontario aligns with this understanding of post-glacial aquatic dispersal and is in fact an expression of its ability to move through lacustrine and riverine pathways as ancient water levels and flow directions changed over time. If so, we expected to be able to suggest when and where the species entered the Great Lakes Basin, facilitating colonization.

\section{Methods}

Sight record information for the Mudpuppy was obtained from the Ontario Reptile and Amphibian Atlas initiative covering the years 1858-2001 (Ontario Nature 2015). Each record is associated with latitude and longitude coordinates, which were qualitatively compared with the various maxima of the ancient Great Lakes (USGS 1917; Clark et al. 2012) using ArcGIS software (ArcGIS Desktop Version 10.3.1., Environmental Systems Research Institute, Redlands, CA, USA). To this end, Mudpuppy sight record information from the Ontario Reptile and Amphibian Atlas was compiled into a spatial database. This was amalgamated with a base map of Southern Ontario showing land elevation and waterbodies (MNR 2012,2013). The approximate extent of historical lakes was then displayed over the base map to allow qualitative assessment of the relation between Mudpuppy records and lake maxima and outlet flow. The maps of Clark et al. (2012) show the changing lake maxima and outlet flow patterns of the ancient Great Lakes for the last 16000 years. These were our basis of reference to determine whether the Mudpuppy's contemporary distribution aligns with some rational model of post-glacial dispersal.

We required three main conditions to conclude that our hypothesis was supported. The first was that connectivity to the Mississippi River system must have occurred at some point previous to facilitate spread of Mudpuppies from their Wisconsinan refugium (Hecht and Walters 1955) into the Great Lakes.

A contribution towards the cost of this publication has been provided by the Thomas Manning Memorial Fund of the Ottawa Field-Naturalist's Club. 
The second was that ancient lake maxima that extended significantly beyond current Mudpuppy range must have existed before Mudpuppy invasion. Otherwise, the greater flooded extent of these ancient lake maxima should have derived current Mudpuppy distribution. We regard this as a safe assumption because otherwise we would need to invoke the non-parsimonious explanation that either i) the Mudpuppy was present in these more-ancient Great Lakes, but perfectly contracted its range with the receding shoreline as water levels fell and did not colonize newly forming inland lakes as this happened, or ii) the Mudpuppy was extirpated from each and every inland lake in which it was left behind and all record of their previous inhabitance was erased. The presence of glacial relict fish (e.g., Lake Trout [Salvelinus namaycush], Spoonhead Sculpin [Cottus ricei]) in inland bodies of water in southern Ontario (Scott and Crossman 1973) suggests that there is no reason to believe any such catastrophe took place in these lakes so as to cause widespread extirpation.

Last, we assumed that the maxima that align most closely with the current distribution of the Mudpuppy are the most likely to have been present when this species entered the Great Lakes. This is because Cochran (1991) concluded that this species' ability to move upstream (and thus away from a shoreline defined by a maximum) is limited. However, we have been mindful that if colonization occurred and was followed by a period of higher water, this assumption must be questioned. Thus, the Mudpuppy's range was forecast to be largely determined by the highest lake maxima since its time of colonization. We used the Mudpuppy's southern Ontario range to validate our inferences about meltwater flow and lake extent.

In addition to these core assumptions, we also assumed that Mudpuppies fully colonized what was available to them and that they have been "deposited" in contemporary inland waterbodies as the ancient maxima fell. This baseline, combined with any upstream immigration, should define their current distribution. Upstream immigration into inland areas should be more pervasive where the substrate is softer and the river grade less violent.

We calculated the average elevation of Mudpuppy records from the Ontario Nature (2015) database $(n=$ $466, \mu=150 \mathrm{~m}$ ). Locations of duplicate records were only included once. We then generated an equal number of random points within a polygon formed by the most peripheral Mudpuppy records (a polygon with no convex angles that included all records), and calculated the same metric for each of these points. A Student's $t$-test run in Excel (Microsoft, Redmond, WA, USA) was used to assess any significant relationships.

\section{Results}

Our Student's $t$-test revealed a significant difference $(P<0.001)$, and suggests that the Mudpuppy's range has been influenced in a topographical sense by some phenomenon in a non-random way.

Among the eight major lake phases as modeled by Clark et al. (2012), the Nipissing Phase's shoreline maxima (USGS 1917) occurring between 4000 and 5000 years ago appears to align most closely with the inland edge of the Mudpuppy's contemporary range when assessed qualitatively. Figure 1 illustrates this tendency for contemporary Mudpuppy records to fall near or within lake maxima from the Nipissing Phase, particularly on the Canadian Shield. The Mudpuppy has been recorded at depths of $27 \mathrm{~m}$ (Reigle 1967); thus, it is important to note that the current range of this species certainly extends out into larger and open parts of the various Great Lakes. These areas do not appear on the map because of the highly unlikely incidence of recording one at these great depths. Thus, the in-shore records that appear in Figure 1 can be considered the inland extent of their range.

\section{Discussion}

The significance of our statistical analysis regarding the elevation of Mudpuppy records supports the notion that a particular phenomenon, such as ancient lake maxima, has had a common influence on this species' range in southern Ontario. Our attempts to identify which maxima this could have been are discussed below.

13000 years ago the water level of Lake Algonquin was very high and flooded what is now Parry Sound, Muskoka, and Simcoe counties, as well as Manitoulin Island and the Bruce Peninsula (Chapman and Putnam 1984; Clark et al. 2012; Drzyzga et al. 2012). Had the Mudpuppy been in this ancient lake, we should expect current records from inland lakes and rivers at or near its maximum. However, there is no trend to support this. "Inland extreme" records of the Mudpuppy from Simcoe, Muskoka, and Parry Sound counties fall farther west than this maximum.

The Mudpuppy's absence from the lakes at this time can be strengthened further by making smaller-scale inferences about meltwater patterns. Harrison (1972) was able to pinpoint the closing date of the Fossmill outlet as $9860 \pm 270$ years ago (calibrated to 1950). This was a major drainage route for Lake Algonquin at the southern edge of the retreating Laurentide glacier that flowed northwest-to-southeast across topographical fissures in the highly elevated and gneiss-dominated Algonquin Dome, forming the modern-day Petawawa River valley (Chapman 1954). Had the Mudpuppy been present in Lake Algonquin at this time, it would have been deposited along the flow of the Fossmill, as were other glacial lake fish and crustacean species (Martin and Chapman 1965). Although absence is harder to detect than presence, multiple decades of fisheries research and a professional naturalist staff have failed to locate the Mudpuppy on the Algonquin Dome and the upper Petawawa River. 


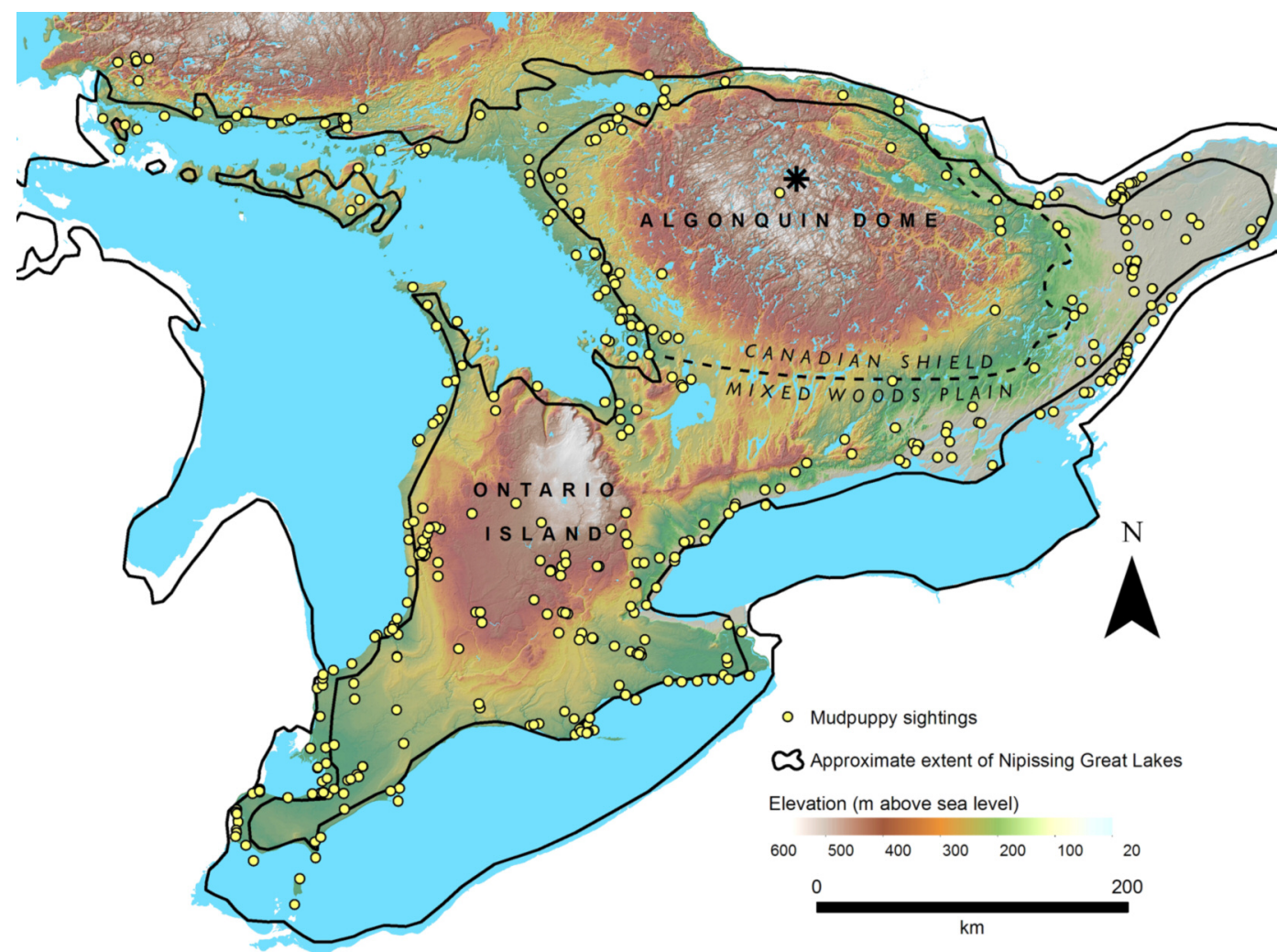

FIGURE 1. Distribution of the Mudpuppy (Necturus maculosus) in southern Ontario in relation to topographical relief/river grade and ancient (Nipissing Phase) and current lake levels, shown in blue. *questionable record from 1945.

Between 13000 and 11800 years ago, Lake Superior drained from the Brule outlet into the Mississippi River (Clark et al. 2012). This also could not have been the Mudpuppy's time and point of entry to the Great Lakes Basin because this species is currently absent from the Mississippi River upstream of St. Anthony Falls (Cochran 1991), a stretch of river downstream from this onceoutlet that should then have been easily colonized.

By 11800 years ago, lake levels were significantly lower even than current levels (Clark et al. 2012). With the higher-level Nipissing maximum coming in the future, it would be impossible to say with certainty whether the Mudpuppy was in the lakes at this time, because this range-defining maximum would have been erased with the yet-to-come higher Nipissing maximum. However, the Great Lakes Basin had no connection to the Mississippi River system at this time (Mandrak and Crossman 1992a; Clark et al. 2012), so feasible dispersal was not possible. Arguments made for the Mudpuppy's entrance into the Great Lakes from the west via ancient Lake Superior are unlikely because the latter was still bound by the Laurentide Ice Sheet at this time.

Although the finer details are still controversial, glacial Lake Agassiz flowed directly into Lake Superior through what is now the Lake Nipigon area approximately 10000 years ago (Fenton et al. 1983). There is no evidence of the Mudpuppy along this drainage route in Ontario today, suggesting it was not present in Lake Agassiz at that time and thus also not in the Great Lakes Basin. This path of flow would have covered what is now contemporary Lake Nipigon. This region's fish have been studied and are exploited both commercially and recreationally (MNR 2009) and yet there are no Mudpuppy records. Mudpuppies are often captured by anglers where they are present (Bishop 1926; Pfingsten and White 1989; Holman 2012), and it seems hard to believe they could have been overlooked here, given the angling culture and work done by the fisheries assessment unit. Further confounding the notion that the Mudpuppy could have been present at this time is the fact that ancient Lake Michigan was also too low to permit a connection to the Mississippi River (Clark et al. 2012) to allow dispersing individuals access into the Great Lakes Basin.

Between 4000 and 5000 years ago (the Nipissing Phase) the maxima of the lakes (USGS 1917) are, for the first time, a close fit with the contemporary distribution of the Mudpuppy on the Canadian Shield. This 
would be expected if this was a time of colonization. There should be little upstream migration into inland areas on the rocky Canadian Shield, and thus the ancient range edge defined by the maxima should still be largely visible. At this time, ancient Lake Michigan had a connection to the Mississippi system via the Sag Channel at its southern extreme (Hansel et al. 1985). Thus, the three conditions are satisfied at this time: there was a connection to the Mississippian refugia to allow dispersal, the maxima of the lakes moreor-less aligns with current records of the Mudpuppy, and there is no logical suite of circumstances that preceded this moment that can offer a better entrance-andcolonization model.

Dispersal routes would have been easily available into ancient Lakes Huron and Superior, which were at the same level as ancient Lake Michigan at this time (Clark et al. 2012). The North Bay outlet, flowing west to east through the Mattawa and Ottawa River basins (Clark et al. 2012), would have been easily traversed by Mudpuppies because of its connectivity to ancient Lake Huron and downstream flow. Saltwater from the Champlain Sea had retreated by this time (Chapman and Putnam 1984) and thus did not influence or halt colonization. Eventually, downstream routes into Lakes Erie and Ontario became available as the Port Huron outlet opened (Coleman et al. 1994; Clark et al. 2012).

Thus, we suggest that Lake Ontario Mudpuppies have arrived there by one or two downstream routes: via the Mattawa/Ottawa/St. Lawrence systems or through the ancient St. Clair and Erie waterway (this would require surviving the drop over Niagara Falls). Because the Nipissing Phase represents the most recent high-water phase of the Great Lakes Basin (Clark et al. 2012), there have likely been only incremental changes in the Mudpuppy's range in the interim, all achieved by surpassing reasonably sized barriers.

\section{The Mudpuppy on the Canadian Shield}

It is clear that the inland records of the Mudpuppy in the northern portions of the map (Figure 1) on the Canadian Shield are less pervasive than further south on the Mixed Woods Plain. On the Canadian Shield, the Algonquin Dome's high elevation and hard rocky substrate (Crins et al. 2009) effectively barred the Mudpuppy from entry to this region (and continues to do so) because of the ragged headwater spillway rivers that drain out from this region.

There is a record for the Mudpuppy in Algonquin Park in the dataset provided by Ontario Nature's herpetofaunal atlas program (Ontario Nature 2015); however, we find this record highly questionable. It is via C. E. Hope in 1945 and is associated with Lake-ofTwo-Rivers (marked with an asterisk in Figure 1). Hope is mentioned in the acknowledgements of the Checklist of Amphibians and Reptiles of Canada and Alaska (Logier and Toner 1955), which does indeed include this Lake-of-Two-Rivers record from Algonquin Park. However, there are too many other unusual elements regarding this record to uphold its integrity. Lake-ofTwo-Rivers sits at $393 \mathrm{~m}$ above sea level and is in one of the highest-elevated areas in Southern Ontario, making it one of the least likely lakes in which Mudpuppies would be found. We have examined photographs of this specimen and it is indeed a Mudpuppy (Royal Ontario Museum \#7533, adult, snout-vent-length 204 $\mathrm{mm}$ [measurement via digital photograph using ImageJ open-source software]), gray with black dorsal spotting). The specimen tag makes no mention of Lake-ofTwo-Rivers, so the origin of the locale information remains questionable. The coordinates $45.83333^{\circ} \mathrm{N}$, $78.5^{\circ} \mathrm{W}$ are associated with this record in an external database, but do not appear on the tag itself; they were certainly added after the fact, and their origin is a mystery (Amy Lathrop, personal communication). In addition, Lake-of-Two-Rivers is located at approximately $45.5^{\circ} \mathrm{N}$, making the suggested latitude many kilometres off target to the north. Even though there is good evidence that Hope was present at Lake-of-Two-Rivers in 1945, we suggest this record is erroneous in some way. No other specimens have been found at this location in the interim after intensive searches (Brad Steinberg, personal communication) and it does not appear that Mudpuppies became established, bred, multiplied, persisted, etc., if they were introduced. It is of interest that Petranka (2010) shows an absence in the distribution of the Mudpuppy in the Adirondack Mountains of New York - a region also with heightened elevation and similar geology to the Algonquin Dome.

\section{The Mudpuppy on the Mixed Woods Plain}

Inland records of the Mudpuppy are more pervasive in the southern portions of the map (Figure 1) on the Mixed Woods Plain than further north on the Canadian Shield, and conformity to the Nipissing Phase maxima is poor. For example, there are a handful of records of the Mudpuppy from the highly elevated "Ontario Island" in Perth, Wellington, and Waterloo counties (Figure 1). Like the high-elevation record at Lake-of-Two-Rivers on the Algonquin Dome, these records may also be questionable. However, high-elevation records of this species off the Canadian Shield, as here, are more likely. Because soft glacial till covers this portion of the province to large depths (Crins et al. 2009), river systems transport massive amounts of sediment, which form graded riffles at points of relief (Wohl 2000). These are easier to traverse in an upstream direction than the more difficult barriers, such as waterfalls, perpetuated by the unyielding gneiss and other rock of the Canadian Shield, as found at Lake-of-Two-Rivers. Some fish species that also face these same barrierchallenges show a similar distribution pattern (see "species distribution pattern C" in Mandrak and Crossman 1992a). For example, the Johnny Darter (Etheostoma nigrum) and the Central Mudminnow (Umbra limi) are found in highly elevated watersheds off the Canadian Shield, but are naturally absent from upland waterbodies on the Canadian Shield (Mandrak and Cross- 
man 1992b). All of the above factors considered, we propose that even pervasively inland records in the Mixed Woods Plain region simply represent populations of the Mudpuppy that were able to steadily climb relatively gentle river grades from initially lower elevations at the levels of the Great Lakes.

Other anomalies in the record database (high-altitude records) that depart geographically from this general model of entrance into and dispersal within the Great Lakes during the Nipissing Phase are probably best explained by changing topography resulting from postglacial isostatic adjustment, anthropogenic changes to watersheds (e.g., canals), as well as Mudpuppies naturally overcoming some barriers. Other apparently anomalous records in the atlas may be attributable to amateur naturalists identifying various superficially similar organisms - catfishes (Ictaluridae), sculpins (Cottidae), gobies (Gobiidae), mole salamander larvae (Ambystomatidae), newts (Salamandridae), etc. - incorrectly as Mudpuppies. The likelihood of misidentification should always be considered when dealing with data derived from citizen-science initiatives.

\section{Conclusion}

Until now, the Mudpuppy has been considered an early, primary invader of the Great Lakes Region following the Wisconsinan glaciation (Holman 2012). However, this notion appears to be based only on this species' ability to be active in cold water. Our more involved work here provides a different explanation for arrival in the Great Lakes Basin. The Nipissing Phase is the most plausible time of entry into the Great Lakes by the Mudpuppy because (i) its maxima most closely align with current distribution records, in particular in rugged regions where upstream, inland migration is hindered; (ii) there was a connection to its Mississippian refugia, which would facilitate spread into the Great Lakes at this time; and (iii) there is no logical ancient suite of circumstances that fit the conditions better.

Our findings suggest that the presence of the Mudpuppy in Ontario can be rationally predicted from knowledge of water flow and flooding during the Nipissing Phase. In short, the Mudpuppy is currently found in all Great Lakes, sparingly inland from Nipissing Phase maxima on the Canadian Shield, and well inland along reasonably traversable river systems on the Mixed Woods Plain. This understanding could be used to evaluate the validity of existing records of this species in the Great Lakes Basin.

Finally, the discussion of the Lake-of-Two Rivers Mudpuppy record presented here (ROM \#7533) illustrates the dangers associated with inferring species ranges without knowledge of the biogeographic factors that led to its distribution on the land and waterscape. We encourage the removal of this record from outputs derived from the Ontario Reptile and Amphibian Atlas database.

\section{Acknowledgements}

We thank the anonymous reviewers and Dan Strickland for reviewing an earlier copy of the manuscript. Dana Buchbinder and Mackenzie Nichols at Ontario Nature were very helpful in providing sight record data. Amy Lathrop of the Royal Ontario Museum was extremely helpful in teasing apart old records. Ron Tozer graciously provided information on the Lake-of-TwoRivers specimen, and Brad Steinberg offered anecdotes of personal experience. David LeGros kindly measured specimen \#7533.

\section{Literature Cited}

Bishop, S. C. 1926. Notes on the habits and development of the mudpuppy, Necturus maculosus (Rafinesque). New York State Museum Bulletin 268: 5-60.

Chapman, L. J. 1954. An outlet of Lake Algonquin at Fossmill, Ontario. Proceedings of the Geological Association of Canada 6: 61-68.

Chapman, L. J., and D. F. Putnam. 1984. The Physiography of Southern Ontario. Ontario Geological Survey Special Volume 2. Ontario Ministry of Natural Resources, Toronto, Ontario, Canada.

Clark, J. A., K. Befus, and G. R. Sharman. 2012. A model of surface water hydrology of the Great Lakes, North America, during the past 16000 years. Physics and Chemistry of the Earth 53-54: 61-71.

Cochran, P. A. 1991. Distribution of the Mudpuppy, Necturus maculosus, in Minnesota in relation to postglacial events. Canadian Field-Naturalist 105: 400-402.

Colman, S. M., R. M. Forester, R. L. Reynolds, D. S. Sweetkind, J. W. King, P. Gangemi, G. A. Jones, L. D. Keigwin, and D. S. Foster. 1994. Lake-level history of Lake Michigan for the past 12000 years: the record from deep lacustrine sediments. Journal of Great Lakes Research 20: 73-92.

Crins, W. J., P. A. Gray, P. W. C. Uhlig, and M. C. Wester. 2009. The ecosystems of Ontario, part I: ecozones and ecoregions. Technical report SIB TER IMA TR-01. Ontario Ministry of Natural Resources, Peterborough, Ontario, Canada.

Drzyzga, S. A., A. M. Shortridge, and R. J. Schaetzl. 2012. Mapping the phases of Glacial Lake Algonquin in the upper Great Lakes region, Canada and USA, using a geostatistical isostatic rebound model. Journal of Paleolimnology 47: 357-371.

Fenton, M. M., S. R. Moran, J. T. Teller, and L. Clayton. 1983. Quaternary stratigraphy and history in the southern part of the Lake Agassiz Basin. Pages 49-74 in Glacial Lake Agassiz. Special Paper 26. Edited by J. T. Teller and L. Clayton. Geological Association of Canada, St. John's, Newfoundland, Canada.

Haffer, J. 1969. Speciation in Amazonian forest birds. Science 165: 131-137.

Hansel, A. K., D. M. Mickelson, A. F. Schneider, and C. E. Larsen. 1985. Late Wisconsinan and Holocene history of the Lake Michigan Basin. In Quaternary Evolution of the Great Lakes. Special Paper 30. Edited by P. F. Karrow and P. E. Calkin. Geological Association of Canada, St. John's, Newfoundland, Canada.

Harrison, J. E. 1972. Quaternary geology of the North BayMattawa region. Paper 71-26. Geological Survey of 
Canada, Department of Energy, Mines, and Resources, Ottawa, Ontario, Canada.

Hecht, M. K., and V. Walters. 1955. On the northern limits of the salamander Necturus maculosus. Copeia 3: 251-252.

Holman, J. A. 1995. Ancient Life of the Great Lakes Basin: Precambrian to Pleistocene. University of Michigan Press, Ann Arbor, Michigan, USA.

Holman, J. A. 2012. The Amphibians and Reptiles of Michigan: A Quaternary and Recent Faunal Adventure. Wayne State University Press, Detroit, Michigan, USA.

Logier, E. B. S., and G. C. Toner. 1955. Check-list of Amphibians and Reptiles of Canada and Alaska. Contributions of the Royal Ontario Museum of Zoology and Palaeontology, no. 41. Royal Ontario Museum, Toronto, Ontario, Canada.

Mandrak, N. E., and E. J. Crossman. 1992a. Postglacial dispersal of freshwater fishes into Ontario. Canadian Journal of Zoology 70: 2247-2259.

Mandrak, N. E., and E. J. Crossman. 1992b. A checklist of Ontario freshwater fishes. Royal Ontario Museum, Toronto, Ontario, Canada.

Martin, N. V., and L. J. Chapman. 1965. Distribution of certain crustaceans and fishes in the region of Algonquin Park, Ontario. Journal of the Fisheries Research Board of Canada 22: 969-976.

MNR (Ministry of Natural Resources). 2009. Fisheries management plan for Fisheries Management Zone 6. Ontario Ministry of Natural Resources, Thunder Bay District, Thunder Bay, Ontario. Canada. Accessed August 2015. https://dr6j45jk9xcmk.cloudfront.net/documents/2613 /271145.pdf.

MNR (Ministry of Natural Resources). 2012. OHN — small scale waterbody (shapefile geospatial data). Spatial Data
Infrastructure Unit, Ontario Ministry of Natural Resources, Peterborough, Ontario, Canada. Accessed 4 August 2015. https://www.javacoeapp.lrc.gov.on.ca/geonetwork/srv/en/ main.home?uuid=5ca7801f-ef2c-4b0a-a930-dac60f1294e1.

MNR (Ministry of Natural Resources). 2013. Provincial digital elevation model - version 3.0. Spatial Data Infrastructure Unit, Ministry of Natural Resources, Peterborough, Ontario, Canada. Accessed 4 August 2015. https://www .javacoeapp.lrc.gov.on.ca/geonetwork/srv/en/main.home? uuid $=012 \mathrm{e} 3632-22 \mathrm{a} 2-49 \mathrm{~d} 8$-bbaf-ad8fbc0d0ceb.

Ontario Nature. 2015. Ontario Reptile and Amphibian Atlas. Ontario Nature, Toronto, Ontario, Canada. Accessed 4 March 2015. http://www.ontarionature.org/atlas.

Petranka, J. W. 2010. Salamanders of the United States and Canada. Smithsonian Books, Washington, DC, USA.

Pfingsten, R. A., and A. M. White. 1989. Necturus maculosus. Pages 72-77 in Salamanders of Ohio. Ohio Biological Survey Bulletin, New Series 7. Edited by R. A. Pfingsten and F. L. Downs. College of Biological Science, Ohio State University, Columbus, Ohio, USA.

Reigle, Jr., N. J. 1967. The occurrence of Necturus in the deeper waters of Green Bay. Herpetologica 23: 232-233.

Scott, W. B., and E. J. Crossman. 1973. Freshwater Fishes of Canada. Bulletin 184. Royal Ontario Museum, Toronto, Ontario, Canada.

USGS (United States Geological Survey). 1917. Map of Nipissing Great Lakes and correlatives. Professional paper 106, plate XXXVIII. USGS, Washington, DC, USA.

Wohl, E. 2000. Mountain rivers. Water resources monograph 14. American Geophysical Union, Washington, DC, USA.

Received 22 August 2015

Accepted 8 March 2016 